\title{
ON THE TEMPERATURE GRADIENT IN THE UPPER PART OF COLD ICE SHEETS
}

\author{
By K. Philberth and B. Federer
}

(Eidg. Institut für Schnee- und Lawinenforschung, Davos, Switzerland)

\begin{abstract}
Amstract. The influence of the surface slope on the temperature profile in the upper part of a cold ice sheet can be described by a function which is independent of the geothermal heat and the heat of friction. This function is calculated for the two-dimensional and the axisymmetric cases. In the two-dimensional case its simplest form is proportional to the horizontal velocity and to the height above bedrock reduced by a constant; another form of this function is approximately proportional to the square of velocity and height.

RÉsumÉ. Sur le gradient de température dans les couches supérieures des calottes glaciaires froides. L'influence de l'inclinaison de la surface sur le profil de température dans la partie supérieure d'une calotte glaciaire froide peut être décrite par une fonction qui est indépendante des chaleurs géothermique et de friction. Cette fonction est calculée pour les cas bidimensionnel et axisymmetrique. Dans le cas bidimensionnel la forme la plus simple de cette fonction est proportionnelle à la vitesse horizontale et à l'altitude sur le lit rocheux diminuée d' une constante; une autre forme est donnée qui est approximativement proportionnelle au carré de ces deux facteurs.

Zusammenfassung. Über den Temperaturgradienten im oberen Teil von kalten Eisschilden. Der Einfluss der Oberflächenneigung auf das Temperaturprofil im oberen Teil eines kalten Eisschildes lässt sich als Funktion beschreiben, die unabhängig ist von der Erd- und der Reibungswärme. Diese Funktion ist für den zweidimensionalen und für den rotationssymetrischen Fall angegeben. Im zweidimensionalen Fall ist ihre einfachste Form proportional der Horizontalgeschwindigkeit und der um eine Konstante reduzierten Höhe über dem Felsboden; eine andere Form ist angenähert proportional dem Quadrat dieser beiden Grössen.
\end{abstract}

\section{INTRODUCTION}

The negative temperature gradient in the upper part of large ice sheets has two sources: The movement of the ice in the $x$-direction and climatic changes. Both effects result in a temperature decrease with depth of the order of $\mathrm{I}$ deg. It is possible to draw conclusions about climatic changes if the influence of the movement is determined precisely.

Theoretical and field work on this subject has been published by Robin (1955, 1970), Bogoslovski (1958), Radok (1959), Weertman (1968), Budd (1969), Budd and others ([1970]), Radok and others (1970), Budd and Radok (197 I). It seems, however, that the following useful solution for the upper part of ice sheets has been overlooked so far.

\section{General solution for the two-dimensional CASE}

The homogeneous form of the heat transport equation under steady-state conditions is

$$
\kappa \partial^{2} T / \partial y^{2}+\kappa \partial^{2} T / \partial x^{2}-v_{y} \partial T / \partial y-v_{x} \partial T / \partial x=0
$$

where $\kappa$ is the diffusivity of ice, $y$ the height above bedrock, $x$ the distance from the ice divide, $v_{y}$ and $v_{x}$ the vertical and horizontal velocities respectively.

In the upper part of the ice sheet, $v_{x}$ is considered to be independent of $y$ (Philberth, B., 1956; Haefeli, 1961; Weertman, 1968; Dansgaard and Johnsen, 1969[b]; Philberth, 1972[b]), and $\partial v_{x} / \partial x$ can be written

$$
\mathrm{d} v_{x} / \mathrm{d} x=v_{x}^{\prime} ; \partial^{2} v_{x} / \partial x^{2}=\mathrm{d}^{2} v_{x} / \mathrm{d} x^{2}=v_{x}^{\prime \prime} .
$$

Using the continuity equation we can write $\partial v_{y} / \partial y=-v_{x}^{\prime}$. Hence $v_{y}=-v_{x}^{\prime} y_{\mathrm{r}}$, where $y_{\mathrm{r}}$, the "reduced height" is equal to $y-h_{0}(x)$. The term $h_{0}(x)$ can be visualized as the height below which the ice has zero velocity and above which it is governed by the block flow law. Usually $h_{0}(x)$ is taken to be zero (Robin, 1955; Weertman, 1968; Budd, 1969; Radok and others, 1970). In this paper we shall use the relation:

$$
y_{\mathrm{r}}=y-h_{0}(x)=y-h\left(\mathrm{r}-v_{x \mathrm{~m}} / v_{x}\right)
$$

where $h=h(x)$ is the total thickness of the ice sheet, $v_{x \mathrm{~m}}$ is the mean value of the horizontal velocity over the total ice sheet and $v_{x}$ is its value in the upper part of the ice sheet. Corresponding to $y_{\mathrm{r}}$ we shall use the "reduced ice-thickness" $h_{\mathrm{r}}=h_{\mathrm{r}}(x)=h(x)-h_{0}(x)$. The ratio $h_{\mathrm{r}} / h$ is equal to $v_{x \mathrm{~m}} / v_{x}$. For the station Jarl Joset, central Greenland, this ratio is 0.9 (Philberth, 1972[b]). 

written

Using $v_{y}=-v_{x}^{\prime} y_{\mathrm{r}}$ and neglecting the heat diffusivity in the $x$-direction, Equation ( $\mathrm{I}$ ) can now be

$$
\kappa \partial^{2} T / \partial y^{2}+v_{x}^{\prime} y_{\mathrm{r}} \partial T / \partial y-v_{x} \partial T / \partial x=0 .
$$

The simplest non-trivial solution of this equation is

$$
T=C_{1} v_{x} y_{\mathrm{r}}
$$

where $C_{1}$, and $C_{0}$ and $C_{2}$ used below, are constants.

If $v_{x} v_{x}^{\prime \prime} / v_{x^{\prime}}{ }^{2}$ is small either with respect to $2 y_{\mathrm{r}}{ }^{2} v_{x}{ }^{\prime} / \kappa$ or to 2 (for station Jarl Joset the first term is 0.15 ; the second term is $>10$, down to a depth of $\mathrm{I} \mathrm{km}$ ), the following approximate solution can also be used

$$
T=C_{2} v_{x^{2}}^{2}\left[y_{\mathrm{r}^{2}}+\kappa / v_{x}^{\prime}\right] .
$$

Solutions with higher powers of $v_{x}$ need not be considered for practical use.

The combination of Equations (4) and (5) leads to the general solution

$$
T=C_{\mathrm{o}}+C_{1} v_{x} y_{\mathrm{r}}+C_{2} v_{x^{2}}\left[y_{\mathrm{r}}^{2}+\kappa / v_{x}^{\prime}\right] .
$$

\section{General SOlUtion FOR DIVERGENT MOVEMENT}

A generalization of Equation (6) for cases of divergent movement can be obtained by introducing a factor $\epsilon$ characterizing the divergence of the streamlines

$$
T=C_{0}+C_{1} v_{x}^{\varepsilon} y_{\mathrm{r}}+C_{2} v^{2 \varepsilon}\left[y_{\mathrm{r}^{2}}+\kappa /\left(\epsilon v_{x}^{\prime}\right)\right] .
$$

In the two dimensional case $\epsilon=\mathrm{I}$. If the accumulation $a$ and the total depth of the ice $h$ are independent of $x, \epsilon$ is 2 in the axisymmetric case and between $\mathrm{I}$ and 2 in intermediate cases. If $a=a(x)$ and $h=h(x)$, however, in the axisymmetric case $\epsilon$ is equal to $\mathrm{I}+\left(\mathrm{d} v_{z} / \mathrm{d} z\right) / v_{x}{ }^{\prime}=\mathrm{I}+\left(v_{x} / x\right) / v_{x}{ }^{\prime}$, where $z$ is the horizontal direction orthogonal to the streamline. If these last expressions are not constant, a mean value along the streamline has to be used.

\section{Application of the two-dimensional solution}

Differentiating Equation (6) with respect to $x$, using $T=T_{\mathrm{s}}$ (surface temperature) and $y=h(x)$, hence $y_{\mathrm{r}}=h_{\mathrm{r}}$, yields

$$
\mathrm{d} T_{\mathrm{s}} / \mathrm{d} x=C_{1} a+{ }_{2} C_{2}\left[a+\kappa / h_{\mathrm{r}}\right] \int_{0}^{x} a d x
$$

where we introduced the substitution $v_{x}=h_{\mathrm{r}}{ }^{-1} \int_{0}^{x} a d x$, with $a=a(x)$ denoting the ice value of the accumulation rate. In Equation (8) the term $\left(C_{2} \kappa v_{x}\right) v_{x} v_{x}{ }^{\prime \prime} / v_{x}^{\prime 2}$ is neglected for the reasons explained in connection with Equation (5). Equation (8) allows us to determine the constants $C_{1}$ and $C_{2}$.

Under normal conditions $\mathrm{d} T_{\mathrm{s}} / \mathrm{d} x$, the horizontal gradient of the surface temperature, and $a(x)$ increase with increasing $x$. If they increase at an equal rate, $C$ - becomes zero. Using Equation (8) with $C_{2}=$ o, Equation (6) becomes

$$
T=\left(a^{-1} \mathrm{~d} T_{\mathrm{s}} / \mathrm{d} x\right) v_{x} y_{\mathrm{r}}=\left(\mathrm{d} T_{\mathrm{s}} / \mathrm{d} x\right) a^{-1} y_{\mathrm{r}} h_{\mathrm{r}}{ }^{-1} \int_{0}^{x} a \mathrm{~d} x .
$$

Near the surface, $y_{\mathrm{r}} / h_{\mathrm{r}}$ approximates $y / h$.

The solutions (4) and (9) do not take into account the heat of friction and the geothermal heat. On the other hand, Robin (1955), Dansgaard and Johnsen (1969[a]) and Philberth and Federer (197 I) calculated vertical temperature profiles taking $T_{\mathrm{s}}$ as independent of $x$ but considering the geothermal and frictional heats. Let $T_{\mathrm{g}}$ be such a profile, which is normalized by the addition of a constant so that it becomes zero at the surface.

The real temperature profile taking into account all three influences, is obtained simply by adding $T_{\mathrm{g}}$ to Equations (6), (7) and (9) respectively. This can be explained in the following way: $T_{\mathrm{g}}$ is the solution of a differential equation, which differs from Equation (I) only by a function of $x$ and $y$ on the right-hand side, expressing the heat of friction. In the case of a linear differential equation, the sum of 
the solutions of the homogeneous plus the inhomogeneous forms is also a solution of the inhomogeneous form. At the surface $T_{\mathrm{g}}$ is zero $\left(T=T_{\mathrm{s}}\right)$, but for $y_{\mathrm{r}}=0$ the function $T$ and its vertical gradient are negligibly small with respect to $T_{\mathrm{g}}$ and its vertical gradient.

Of practical significance is the fact that in the upper part (region with negative temperature gradient) not only $T$ but also $T_{\mathrm{g}}$ can be calculated in a simple way. In the upper part $T_{\mathrm{g}}$ can be taken as independent of $x$ (e.g. according to Robin, 1955, equation (8) or Philberth and Federer, 1971, table I). This can be verified as follows: The upper part of the ice sheet is influenced by a heat of friction which is much smaller than the heat of friction produced below point $x$, because it originated at a considerably smaller $x$ and $v_{x}$. Therefore its influence is normally much smaller than the ( $x$-independent) geothermal heat and can be neglected or approximated by a function which does not depend on $x$. The horizontal gradient $\partial T_{\mathrm{g}} / \partial x$ depends on $\mathrm{d} h / \mathrm{d} x$ and $\mathrm{d} a / \mathrm{d} x$; but Weertman's (1968) equation (6b) for $\mathrm{d} T_{\mathrm{s}} / \mathrm{d} x=0$ (his $\mathrm{d} T_{\mathrm{u}} / \mathrm{d} x$ ) shows $\partial T_{\mathrm{g}} / \partial x$ to be very small in the range where $T-T_{\mathrm{s}}$ is small.

\section{An example: station Jarl Joset (LAT. $33^{\circ} 30^{\prime}$ W., LONG. $71^{\circ} 20^{\prime}$ N., 2865 m A.s.L.}

General values:

$$
\kappa=40 \mathrm{~m}^{2} \mathrm{a}^{-1} \text {; temperature lapse rate } \lambda=9.5 \mathrm{deg} \mathrm{km}^{-1} \text {. }
$$

Local values:

$$
h=2.500 \mathrm{~km} ; h_{\mathrm{r}}=2.250 \mathrm{~km} ; x=125 \mathrm{~km} \text { (Philberth, 1972[b]). }
$$

Values between ice divide and Farl Foset:

$a=0.30 \mathrm{~m} \mathrm{a}^{-1}$ ice value (independent of $x$; Federer and others, 1970), $\epsilon=\mathrm{I}$ (two dimensional case; Philberth, in press), height of surface $=3.160 \mathrm{~km}-1.4 \times 10^{-3} x-7.5 \times 10^{-6} \mathrm{~km}^{-1} x^{2}$ (Mälzer, 1964; Lliboutry, 1968; Philberth and Federer, 1970).

\section{Derived relations:}

Multiplication of Equation (10) by $\lambda$ yields

$$
\begin{gathered}
T_{\mathrm{s}}=\text { const. }+\mathrm{r} 3.3 \times \mathrm{ro}^{-3} \mathrm{deg} \mathrm{km}^{-1} x+7 \mathrm{r} \times \mathrm{ro}^{-6} \mathrm{deg} \mathrm{km}^{-2} x^{2}, \\
v_{x}=h_{\mathrm{r}}{ }^{-1} \int_{0}^{x} a \mathrm{~d} x=a x / h_{\mathrm{r}} ;
\end{gathered}
$$

according to Equation (6) we have:

$$
T=C_{0}+C_{1} a x y_{\mathrm{r}} / h_{\mathrm{r}}+C_{2} a^{2}\left[y_{\mathrm{r}^{2}} / h_{\mathrm{r}^{2}}+\kappa /\left(a h_{\mathrm{r}}\right)\right] x^{2} .
$$

The comparison of $\mathcal{T}$ for $y_{\mathrm{r}}=h_{\mathrm{r}}$ with $T_{\mathrm{s}}$ yields:

$$
T=C_{0}+13.3 \times 10^{-3} \mathrm{deg} \mathrm{km}-1 \times y_{\mathrm{r}} / h_{\mathrm{r}}+67 \times \mathrm{ro}^{-6} \mathrm{deg} \mathrm{km}^{-2}\left[y_{\mathrm{r}^{2}} / h_{\mathrm{r}^{2}}+0.06\right] x^{2} .
$$

For $x=125 \mathrm{~km}$ (Jarl Joset) the result is:

$$
T-T_{\mathrm{s}}=\left[-2.7 \mathrm{r}+\mathrm{I} .66 y_{\mathrm{r}} / h_{\mathrm{r}}+\mathrm{I} .05 y_{\mathrm{r}}^{2} / h_{\mathrm{r}}{ }^{2}\right] \mathrm{deg} .
$$

\section{Comparison with measured values:}

At the depth of $615 \mathrm{~m}\left(y_{\mathrm{r}}=1635 \mathrm{~m}\right)-29.30^{\circ} \mathrm{C}$ and at $1005 \mathrm{~m}\left(y_{\mathrm{r}}=1245 \mathrm{~m}\right)-30.00^{\circ} \mathrm{C}$ have been measured by the thermal probe method (Philberth, 1962, 1970); that is a difference of $0.70 \mathrm{deg}$. For these two depths the Equation ( $\mathrm{I}$ I) yields a difference of $0.5^{2} \mathrm{deg}$ and the function $T_{\mathrm{g}}$ yields a difference of $-0.32 \mathrm{deg}$. Hence the total amount of the theoretical difference for steady-state conditions is $0.20 \mathrm{deg}$.

The measured value $(0.70 \mathrm{deg})$ and theoretical value $(0.20 \mathrm{deg})$ differ by $0.50 \mathrm{deg}$, which can be explained by palaeoclimatic changes. If a temperature jump $\theta$ (end of ice age) is assumed to be at ro 000 years B.P. (Dansgaard and others, 1969), the $0.50 \mathrm{deg}$ difference corresponds to $\theta=5 \mathrm{deg}$, if the jump is assumed to be at 12 ooo years B.P., it corresponds to $\theta=6 \operatorname{deg}$ (Philberth, $1972[\mathrm{a}]$ ).

MS. received 3 April 1973 and in revised form II Fuly 1973 


\section{REFERENGES}

Bogoslovskiy, V. N. 1958 . The temperature conditions (regime) and movement of the Antarctic glacial shield. Union Géodésique et Géophysique Internationale. Association Internationale d'Hydrologie Scientifique. Symposium de Chamorix, $16-24$ sept. 1958, p. 287-305.

Budd, W. F. 1969. The dynamics of ice masses. ANARE Scientific Reports. Ser. A(IV). Glaciology. Publication No. 108.

Budd, W. F., and Radok, U. 1971. Glaciers and other large ice masses. Reports on Progress in Physics, Vol. 34, No. I, p. I-70.

Budd, W. F., and others. [1970.] The extent of basal melting in Antarctica, by W. [F.] Budd, D. Jenssen and U. Radok. Polarforschung, Bd. 6, Jahrg. 39, Nr. I, 1969, p. 293-306.

Dansgaard, W., and Johnsen, S. J. I969[a]. Comment on paper by J..Weertman, "Comparison between measured and theoretical temperature profiles of the Camp Century, Greenland, borehole". Fournal of Geophysical Research, Vol. 74, No. 4, p. I ro9-10.

Dansgaard, W., and Johnsen, S. J. $1969[\mathrm{~b}]$. A flow model and a time scale for the ice core from Camp Century, Greenland. Journal of Glaciology, Vol. 8, No. 53, p. 215-23.

Dansgaard, W., and others. r 969 . One thousand centuries of climatic record from Camp Century on the Greenland ice sheet, by W. Dansgaard, S. J. Johnsen, J. Møller and C. C. Langway, Jr. Science, Vol. ı66, No. 3903, p. $377-81$.

Federer, B., and others. I970. Outflow and accumulation of ice in Jarl-Joset station, Greenland, by B. Federer, H. V. Sury, K. Philberth and M. [R.] de Quervain. Journal of Geophysical Research, Vol. 75, No. 24, p. 4567-69.

Haefeli, R. 1961. Contribution to the movement and the form of ice sheets in the Arctic and Antarctic. Fournal of Glaciology, Vol. 3, No. 30, p. 1 1 33-51.

Lliboutry, L. A. 1968. Steady-state temperatures at the bottom of ice sheets and computation of the bottom ice flow law from the surface profile. Fournal of Glaciology, Vol. 7, No. 51, p. 363-76.

Mälzer, H. 1964. Das Nivellement über das grönländische Inlandeis der Internationalen Glaziologischen Grönland-Expedition 1959. Meddelelser om Gronland, Bd. 173, Nr. 7.

Philberth, B. 1956. Beseitigung radioaktiver Abfallsubstanzen. Atomkern-Energie (München), I. Jahrg., Ht. 1 1-1 2, p. $396-400$.

Philberth, K. 1962. Une méthode pour mesurer les températures a l'intérieur d'un inlandsis. Comptes Rendus Hebdomadaires des Séances de l'Académie des Sciences (Paris), Tom. 254, No. 22, p. $388 \mathrm{I}-83$.

Philberth, K. 1970. Thermische Tiefbohrung in Zentralgrönland. Umschaı in Wissenschafı und Technik, 1970, Ht. I6, p. 515-16.

Philberth, K. 1972 [a]. Factors affecting deep ice temperatures. Nature, Physical Science, Vol. 237, No. 72, p. 44-45.

Philberth, K. $1972[\mathrm{~b}]$. Über den inneren Wärmehaushalt in mächtigen Eisschilłen. Polarforschung, Bd. 7, 42. Jahrg., Nr. I, p. I I-I 7 .

Philberth, K. In press. Die thermische Tiefbohrung in Station Jarl-Joset und ihre theoretische Auswertung. Meddelelser om Gronland.

Philberth, K., and Federer, B. 1970. A note on the surface profile of the Greenland ice sheet. Journal of Glaciology, Vol. 9, No. 55, p. ${ }^{1} 50-53$.

Philberth, K., and Federer, B. 1971. On the temperature profile and the age profile in the central part of cold ice sheets. Journal of Glaciology, Vol. 10, No. 58, p. 3-14.

Radok, U. 1959. Temperatures in polar ice caps. Nature, Vol. 184, No. 4692, p. 1056-57.

Radok, U., and others. 1970. Steady-state temperature profiles in ice sheets, by U. Radok, D. Jenssen and W. [F.] Budd. [Union Géodésique et Géophysique Internationale. Association Internationale d'Hydrologie Scientifique.] [International Council of Scientific Unions. Scientific Committee on Antarctic Research. International Association of Scienlific Hydrology. Commission of Snow and Ice.] International Symposium on Antarctic Glaciological Exploration (ISAGE), Hanover, New Hampshire, U.S.A., 3-7 September 1963 , p. $151-65$.

Robin, G. de Q. 1955. Ice movement and temperature distribution in glaciers and ice shects. Journal of Glaciology, Vol. 2, No. 18, p. 523-32.

Robin, G. de Q. 1970. Stability of ice sheets as deduced from deep temperature gradients. [Union Géodésique et Géophysique Internationale. Association Internationale d'Hydrologie Scientifique.] [International Council of Scientific Unions. Scientific Committee on Antarctic Research. International Association of Scientific Hydrology. Commission of Snow and Ice.] International Symposium on Antarctic Glaciological Exploration (ISAGE), Hanvver, New Hampshire, U.S.A., 3-7 September 1963, p. 141-51.

Weertman, J. 1968. Comparison between measured and t'ieoretical temperature profiles of the Camp Cer.tary, Greenland, borehole. Journal of Geophysical Research, Vol. 73, No. 8, p. 2691-70o. 